\title{
PENGARUH LINGKUNGAN KERJA DAN JOB INSECURITY TERHADAP MOTIVASI KERJA DAN DAMPAKNYA PADA KINERJA KARYAWAN OUTSOURCING MALL LIPPO CIKARANG
}

\author{
Lim Sanny; Selby Kristanti \\ Jurusan Manajemen, Fakultas Ekonomi dan Komunikasi, BINUS University \\ Jln. K.H. Syahdan No 9, Palmerah, Jakarta Barat 11480
}

\begin{abstract}
Mal Lippo Cikarang a shopping center that uses outsourcing employees to manager level down. The purpose of this study is to analyze the influence of work environment and job insecurity on work motivation and its impact on employee performance Outsourcing in Lippo Cikarang Mall. The method of analysis used in this study are Pearson correlation and path analysis. Data obtained from the assessment of employees through questionnaires and interviews. Results achieved in this study was to determine that the work environment at the Mall Lippo Cikarang less convenient and there is job insecurity on the company and therefore contributes less well on work motivation and employee performance Outsourcing in Lippo Cikarang Mall. Job insecurity has a weak and a significant effect on work motivation and employee performance and work environment has a fairly strong relationship and significant impact on employee motivation and performance. Motivation to work has a strong relationship to the employee's performance. With the company is expected to focus on increasing motivation and improving the working environment at the Mall Lippo Cikarang and member attention on job insecurity. In addition, the expected results of this research can provide input to the Mall Lippo Cikarang so as to improve employee performance Outsourcing as well.
\end{abstract}

Keywords: outsourcing, working environment, job insecurity, motivation, employee performance

\begin{abstract}
ABSTRAK
Mal Lippo Cikarang sebuah pusat perbelanjaan yang memakai karyawan outsourcing untuk level manager ke bawah. Tujuan penelitian ini adalah menganalisa pengaruh lingkungan kerja dan Job Insecurity terhadap motivasi kerja dan dampaknya pada kinerja karyawan Outsourcing di Mall Lippo Cikarang. Metode analisa yang digunakan dalam penelitian ini adalah korelasi pearson dan Path Analysis. Data diperoleh dari penilaian karyawan melalui kuesioner dan wawancara. Hasil yang dicapai dalam penelitian ini adalah mengetahui bahwa lingkungan kerja di Mall Lippo Cikarang kurang nyaman dan terdapat Job Insecurity pada perusahaan sehingga berpengaruh kurang baik terhadap Motivasi kerja dan Kinerja karyawan Outsourcing di Mall Lippo Cikarang. Job Insecurity memiliki hubungan yang lemah dan pengaruh yang signifikan terhadap Motivasi kerja dan Kinerja karyawan dan lingkungan kerja memiliki hubungan yang cukup kuat dan signifikan terhadap Motivasi dan Kinerja karyawan. Motivasi kerja memiliki hubungan yang kuat terhadap kinerja karyawan. Dengan ini diharapkan perusahaan dapat berfokus pada peningkatan motivasi kerja dan perbaikan lingkungan kerja di Mall Lippo Cikarang serta member perhatian pada Job Insecurity. Selain itu, diharapkan hasil penelitian ini dapat memberi masukan kepada Mall Lippo Cikarang sehingga dapat meningkatkan kinerja karyawan Outsourcing dengan baik.
\end{abstract}

Kata kunci: outsourcing, lingkungan kerja, job insecurity, motivasi kerja, kinerja karyawan 


\section{PENDAHULUAN}

Setiap perusahaan pada dasarnya mempunyai tujuan untuk memperoleh keuntungan yang semaksimal mungkin dan juga berharap untuk dapat meminimumkan biaya-biaya yang dikeluarkan guna menjaga kelangsungan hidupnya. Perusahaan perlu melakukan menyerahkan proses-proses yang bukan merupakan core compentence perusahaan tersebut ke pihak ketiga. Outsourcing adalah pendelegasian operasi dan manajemen harian dari suatu proses bisnis kepada pihak luar (perusahaan penyedia jasa Outsourcing).

Maraknya sistem kontrak dan outsourcing yang tentunya berdampak secara signifikan di dalam hubungan ketenagakerjaan antara karyawan dan perusahaan manajemen. Dengan adanya hal tersebut, maka intensitas munculnya Job Insecurity menjadi semakin tinggi dirasakan oleh karyawan. Job Insecurity dapat mempengaruhi motivasi kerja para karyawan Outsourcing karena merasa tidak aman, dimana mereka hanya berstatus kontrak. Dan para karyawan pun juga memerlukan lingkungan kerja yang sesuai untuk mereka agar merasa nyaman saat bekerja.

Di dalam melakukan pekerjaannya, setiap karyawan sebagai seorang manusia tentunya sangat mendambakan kenyamanan dan keamanan dalam bekerja. Keamanan di dalam konteks ini bukan berarti hanya aman dari kecelakaan kerja, tetapi jauh dari itu, rasa aman dari ancaman kehilangan pekerjaan. Perasaan aman ini dapat menjadi suatu stimulator yang luar biasa di dalam mempertahankan sikap kerja karyawan secara jangka pajang. Lingkungan kerja juga merupakan salah satu aspek yang tidak kalah penting, karena kebersihan, keharmonisan antar karyawan, dan keamanan akan meningkatkan motivasi karyawan dalam bekerja.

Pada umumnya kinerja yang tinggi dihubungkan dengan motivasi yang tinggi. Sebaliknya, motivasi yang rendah dihubungkan dengan kinerja yang rendah. Kinerja seseorang kadang-kadang tidak berhubungan dengan kompetensi yang dimiliki, karena terdapat faktor diri dan lingkungan kerja yang mempengaruhi kinerja.

Mal Lippo Cikarang yang beralamatkan di Jalan M.H.Thamrin merupakan perusahaan yang memakai karyawan outsourcing untuk level manager ke bawah. Beberapa pengunjung dari Mal Lippo Cikarang kadang mengeluh cara kerja karyawan di Mal Lippo Ckarang yang kurang baik. Motivasi kerja mereka kadang terlihat kurang. Lingkungan kerja yang mereka alami mungkin menjadi faktor yang mempengaruhi motivasi meraka dan pemikiran ketidakamanan mereka dalam bekerja karena hanya berstatus Outsourcing. Hal ini secara langsung dapat mempengaruhi kinerja para karyawan Mall sehari-hari.

Peneliti menduga faktor lingkungan kerja dan Job Insecurity mempengaruhi motivasi kerja di Mal Lippo Cikarang yang cenderung menurun belakangan ini, dan kinerja mereka terkena dampak nya juga. Oleh karena itu, penulis akan mengadakan penelitian dengan judul Pengaruh Lingkungan Kerja dan Job Insecurity Terhadap Motivasi Kerja dan Dampaknya Pada Kinerja Karyawan Outsourcing (Studi Kasus Mal Lippo Cikarang).

Berdasarkan data-data yang telah diperoleh sebelumnya serta melihat jumlah variabel yang digunakan dalam penelitian ini, terdapat 2 identifikasi masalah yang akan dibahas, yaitu: (1) adakah pengaruh Lingkungan Kerja dan Job Insecurity terhadap Motivasi Kerja Karyawan Outsourcing di Mal Lippo Cikarang; (2) adakah pengaruh lingkungan kerja, job insecurity dan motivasi kerja terhadap kinerja karyawan Outsourcing di Mall Lippo Cikarang?

Berdasarkan identifikasi masalah diatas maka penulis memperoleh tiga tujuan penelitian, antara lain: (1) untuk mengetahui pengaruh lingkungan kerja dan job insecurity terhadap motivasi kerja karyawan outsourcing di Mal Lippo Cikarang; dan (2) untuk mengetahui pengaruh lingkungan 
kerja, job insecurity dan motivasi kerja terhadap kinerja karyawan Outsourcing di Mall Lippo Cikarang.

\section{Kajian Pustaka}

\section{Outsourcing}

Menurut Bin Jiang, et al. (2006), Outsourcing dapat meningkatkan biaya perusahaan-efisiensi. Belum pernah outsourcing bermain seperti peranan penting dalam bisnis, namun dampak keseluruhan outsourcing terhadap kinerja sebagian besar masih merupakan kontroversi bagi perusahaan (segi positif), dan bagi karyawan Outsourcing (segi negatif).

Efisiensi dapat diartikan sebagai perbandingan antara sumber yang dipergunakan dengan output yang dihasilkan. Terdapat 2 efisiensi Outsourcing, yaitu: (1) technical efficiency, yaitu berusaha menghasilkan output yang sama dengan input lebih kecil maupun usaha menghasilkan output yang lebih besar dengan input sama; dan (2) input trade off efficiency, yaitu berusaha menghasilkan output yang sama dengan jumlah input yang sama tetapi harga lebih murah.

Menurut Mardiana dalam Sofyandi (2008), Lingkungan kerja adalah lingkungan dimana pegawai melakukan pekerjaannya sehari-hari. Jika pegawai menyenangi lingkungan kerja dimana dia bekerja, maka pegawai tersebut akan betah di tempat kerjanya untuk melakukan aktivitas sehingga waktu kerja dipergunakan secara efektif dan optimis prestasi kerja pegawai juga tinggi. Lingkungan kerja tersebut mencakup hubungan kerja yang terbentuk antara sesama pegawai dan hubungan kerja antar bawahan dan atasan serta lingkungan fisik tempat pegawai bekerja.

Sedarmayanti (2001) menyatakan bahwa secara garis besar lingkungan kerja terbagi menjadi 2 yakni: lingkungan kerja fisik dan lingkungan kerja non fisik, yaitu: (1) lingkungan kerja fisik adalah semua keadaan berbentuk fisik yang terdapat di sekitar tempat kerja yang dapat mempengaruhi karyawan baik secara langsung, maupun secara tidak langsung, antara lain: penerangan cahaya di tempat kerja, temperatur di tempat kerja, kelembaban di tempat kerja, sirkulasi udara di tempat kerja, kebisingan di tempat kerja, getaran mekanis di tempat kerja, bau-bauan di tempat kerja, tata warna ditempat kerja, dekorasi di tempat kerja, musik di tempat kerja dan keamanan di tempat kerja; (2) Lingkungan kerja non fisik adalah semua keadaan yang terjadi yang berkaitan dengan hubungan kerja baik hubungan dengan atasan maupun dengan bawahan serta hubungan dengan rekan kerja. Menurut Basuki \& Susilowati (2005) apabila lingkungan kerja meningkat, maka semangat kerja juga akan meningkat, Peningkatan lingkungan kerja dapat dilakukan dengan cara menciptakan suasana kerja dalam perusahaan yang menyenangkan dengan kebersihan yang ada, hubungan antara karyawan yang harmonis harus dipertahankan.

\section{Job Insecurity}

Menurut Rony \& Bram (2008), fenomena ketidakamanan pekerjaan bukan merupakan istilah baru dalam lingkungan bisnis organisasi. Ketidakamanan pekerjaan adalah kondisi dimana karyawan merasa terancam oleh ketidakpastian keberlanjutan dalam bekerja di organisasi mereka. Penampilan ketidakamanan kerja akan menimbulkan dampak negatif terhadap fisik dan psikologis karyawan baik dalam jangka panjang dan jangka pendek.

Pasewark dan Strawser (2001) menerangkan mengenai empat variabel pendahulu (anteseden), yang oleh Suwandi dan Indriantoro (2003) disebut prediktor, dari job insecurity berdasarkan hasil studi sebelumnya, yaitu: konflik peran (role conflict), ketidakjelasan peran (role ambiguity), perubahan organisasi (organizational change), dan pusat pengendalian (locus of control). Sedangkan 
konsekuensi dari job insecurity tersebut adalah komitmen organisasional, kepuasan kerja, dan kepercayaan organisasi.

\section{Motivasi}

Motivasi merupakan sebuah alasan atau dorongan seseorang untuk bertindak. Orang yang tidak mau bertindak sering kali disebut tidak memiliki motivasi. Alasan atau dorongan itu bisa datang dari luar maupun dari dalam diri. Dalam hubungannya dengan lingkungan kerja, McCormick dalam Mangkunegara (2002) mengemukakan bahwa motivasi kerja didefinisikan sebagai kondisi yang berpengaruh membangkitkan, mengarahkan dan memelihara perilaku yang berhubungan dengan lingkungan kerja.

Menurut George dan Jones (2005), seorang psikolog, Abraham Maslow menyatakan bahwa manusia memiliki 5 kebutuhan universal yang mereka cari untuk dipuaskan: Kebutuhan fisiologi, kebutuhan rasa aman, kebutuhan social, kebutuhan rasa penghargaan, dan kebutuhan aktualisasi diri. Malow menyatakan bahwa setelah suatu kebutuhan terpuaskan, maka tidak lagi menjadi sumber motivasi.

\section{Kinerja}

Menurut Mathis \& Jackson (2006), kinerja (performance) pada dasarnya adalah apa yang dilakukan atau tidak dilakukan oleh karyawan. Kinerja adalah kesediaan seseorang atau kelompok orang untuk melakukan sesuatu kegiatan dan menyempurnakannya sesuai dengan tanggung jawabnya dengan hasil seperti yang diharapkan.

Menurut Robert dan John (2006), kinerja karyawan yang umum meliputi: kualitas dan hasil, waktu dan kecepatan dari hasil, kehadiran atau absensi, kemampuan bekerja sama dan rasa dapat dipercaya.

\section{Model Penelitian}

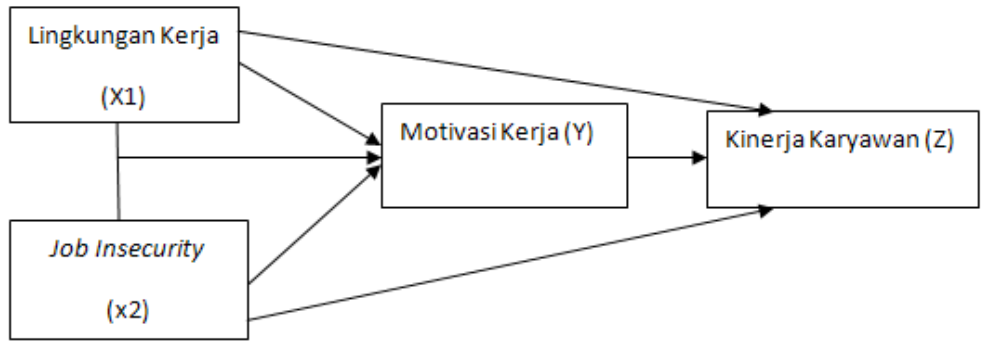

Gambar 1 Model Penelitian

\section{METODE}

Pengamatan dilakukan terhadap karyawan Outsourcing Mall Lippo Cikarang. Jenis penelitian yang digunakan adalah asosiatif. Dengan penelitian asosiatif ini dapat diketahui pengaruh variabel independen terhadap variabel dependen. Dalam pelaksanaannya metode penelitian yang dilakukan adalah survey. Unit analisis yang dituju adalah individu, yaitu para karyawan Outsourcing Mall Lippo Cikarang. 
Penelitian ini digunakan cara sensus, yaitu dengan mengambil semua populasi yang ada, karena jumlah populasinya relative sedikit. Populasi dalam penelitian ini adalah pekerja Outsourcing yang berjumlah 102 karyawan. Dalam penelitian ini, pengumpulan data dilakukan dengan cara membagikan kuisioner dan wawancara.

\section{Metode Analisis}

\section{Uji Normalitas}

Dasar pengambilan keputusan: 1) Nilai signifikansi (sig) atau nilai probabilitas $<0,05$, data tidak terdistribusi secra normal. 2) Nilai signifikansi (sig) atau nilai probabilitas $>0,05$, data terdistribusi secara normal.

\section{Uji Validitas}

Uji validitas dilakukan berkenaan dengan ketepatan alat ukur terhadap konsep yang diukur sehingga benar-benar mengukur apa yang seharusnya diukur. Berkaitan dengan pengujian validitas instrument menurut Riduwan (2007) menjelaskan bahwa validitas adalah suatu ukuran yang menunjukkan tingkat keandalan suatu alat ukur.

\section{Uji Reliabilitas}

Reliabilitas adalah tingkat keterpercayaan hasil suatu pengukuran (Rochaety et al. 2007:49) sehingga akan menunjukkan apakah kuesioner yang dipakai dapat secara konsisten memberi hasil ukuran yang sama tentang suatu yang diukur pada waktu yang berbeda.

\section{Korelasi Pearson}

Berdasarkan Riduwan dan Kuncoro (2008) untuk mengetahui hubungan antara variabel $\mathrm{X}_{1}$ dengan $\mathrm{Y}$ dan $\mathrm{X}_{2}$ dengan $\mathrm{Y}$ dan $\mathrm{X}_{1}$ dan $\mathrm{X}_{2}$ terhadap $\mathrm{Y}$ digunakan teknik korelasi.

\section{Path Analysis}

Analisis jalur adalah suatu teknik untuk menganalisis hubungan sebab akibat yang terjadi pada regresi berganda jika variable bebasnya mempengaruhi variable tergantung tidak hanya secara langsung, tetapi juga secara tidak langsung.

\section{HASIL DAN PEMBAHASAN}

\section{Transformasi Data Ordinal menjadi Interval}

Data yang diperoleh dari kuesioner berupa data dalam skala Ordinal akan diubah menjadi interval dengan menggunakan MSI (Method of Successive Interval) yang dilakukan per variable.

\section{Uji Validitas ,Reliabilitas, dan Normalitas Kuesioner}

Lingkungan Kerja (X1)

R hitung P1- P13 $>$ R table $(0.16) \rightarrow$ valid, Cronbach's Alpha $0.858>0.16$ (reliable). Signifikasi Uji Kolmogorov-Smirnov $0.200>0.05$ (data berdistribusi normal)

Job Insecurity (X2) 
R hitung P14- P24 > R table(0.16) $\rightarrow$ valid, Cronbach's Alpha $0.857>0.16$ (reliable). Signifikasi Uji Kolmogorov-Smirnov $0.074>0.05$ (data berdistribusi normal)

Motivasi Kerja (Y)

R hitung P25- P32 > R table(0.16) $\rightarrow$ valid, Cronbach's Alpha $0.814>0.16$ (reliable). Signifikasi Uji Kolmogorov-Smirnov $0.200>0.05$ (data berdistribusi normal)

Kinerja Karyawan $(Z)$

R hitung P1- P13 $>$ R table $(0.16) \rightarrow$ valid, Cronbach's Alpha $0.757>0.16$ (reliable). Signifikasi Uji Kolmogorov-Smirnov $0.164>0.05$ (data berdistribusi normal).

\section{Analisis Korelasi}

Tabel 1 Correlations

\begin{tabular}{|c|c|c|c|c|c|}
\hline \multicolumn{6}{|c|}{ Correlations } \\
\hline & & $\mathrm{x} 1$ & $\times 2$ & $y$ & $z$ \\
\hline \multirow[t]{3}{*}{$\mathrm{x} 1$} & Pearson Correlation & 1 & .018 & $434^{\circ}$ & $434^{*}$ \\
\hline & Sig. (2-tailed) & & .057 & .000 & .000 \\
\hline & $N$ & 102 & 102 & 102 & 102 \\
\hline \multirow[t]{3}{*}{$x 2$} & Pearson Correlation & .0 .8 & 1 & -.114 & -.092 \\
\hline & Sig. (2-tailed) & .057 & & .015 & .044 \\
\hline & $\mathrm{N}$ & 102 & 102 & 102 & 102 \\
\hline \multirow[t]{3}{*}{$y$} & Pearson Correlation & $434^{\circ}$ & -.114 & 1 & $.715^{\circ}$ \\
\hline & Sig. (2-tailed) & .000 & .015 & & .000 \\
\hline & $\mathrm{N}$ & 102 & 102 & 102 & 102 \\
\hline \multirow[t]{3}{*}{$z$} & Pearson Correlation & $434^{\circ}$ & -.092 & $.715^{*}$ & 1 \\
\hline & Sig. (2-tailed) & .000 & .044 & .000 & \\
\hline & $N$ & 102 & 102 & 102 & 102 \\
\hline
\end{tabular}

Sumber: Hasil Pengolahan Data (2011)

\section{Path Analysis}

Analisis Pengaruh Lingkungan Kerja(x1) dan Job Insecurity (x2) terhadap Motivasi Kerja (y)Pengujian Sub-Struktural 1

Tabel 2 Model Summary Sub-Struktural 1

\begin{tabular}{|c|c|c|c|c|}
\hline \multicolumn{5}{|c|}{ Model Summary } \\
\hline Mode & $\mathrm{R}$ & F Square & $\begin{array}{c}\text { Adjusted R } \\
\text { Bquare }\end{array}$ & $\begin{array}{l}\text { Std. Error of } \\
\text { the Estimate }\end{array}$ \\
\hline 1 & $451=$ & .203 & .187 & .56569 \\
\hline
\end{tabular}

Dari Tabel 2, diketahui bahwa variabel Lingkungan kerja $\left(\mathrm{X}_{1}\right)$ dan Job Insecurity $\left(\mathrm{X}_{2}\right)$ terhadap Motivasi Kerja $(\mathrm{Y})$ sebesar $\mathrm{R}$ Square $\left(\mathrm{R}^{2}\right)$ adalah $0.203=20,3 \%$ dan besarnya pengaruh variabel lain yang mempengaruhi variabel motivasi Kerja (Y) diluar penelitian ini adalah sebesar $79,7 \%$. sementara itu, besarnya koefisien jalur bagi variabel lain diluar penelitian yang mempengaruhi dapat dihitung melalui rumus sebagai berikut : 


$$
\begin{aligned}
\rho_{\mathrm{y}} \varepsilon_{1} & =\sqrt{1-\mathrm{R}^{2} \mathrm{xy}} \\
& =\sqrt{1-0.203} \\
& =0.892
\end{aligned}
$$

\begin{tabular}{|c|c|c|c|c|c|c|}
\hline \multirow{2}{*}{\multicolumn{2}{|c|}{ Model }} & \multicolumn{2}{|c|}{ Unstandardized Coefficients } & \multirow{2}{*}{$\begin{array}{c}\text { Standardized } \\
\text { Coefficients } \\
\text { Beta } \\
\end{array}$} & \multirow[b]{2}{*}{$t$} & \multirow[b]{2}{*}{ Sig. } \\
\hline & & $\mathrm{B}$ & Std. Error & & & \\
\hline \multirow[t]{3}{*}{1} & (Constant) & 2.264 & .424 & & 5.346 & .000 \\
\hline & $x 1$ & .477 & .098 & .437 & 4.866 & .000 \\
\hline & $\times 2$ & -.128 & .094 & -.122 & -1.355 & .150 \\
\hline
\end{tabular}

Tabel 3 Coefficient Sub-Sturktural 1

Coefficients $^{\text {a }}$

a. Dependent Variable: $y$

Sumber : Hasil Pengolahan Data Peneliti (2011)

$$
\begin{aligned}
& Y=\rho_{\mathrm{yx} 1} \mathrm{X}_{1}+\rho_{\mathrm{yx} 2} \mathrm{X}_{2}+\rho_{\mathrm{y}} \varepsilon_{1} \\
& \mathrm{Y}=0.437 \mathrm{X}_{1}-0.122 \mathrm{X}_{2}+0.892 \varepsilon_{1}
\end{aligned}
$$

Analisis Pengaruh Lingkungan Kerja (x1), Job Insecurity (x2) terhadap Motivasi Kerja (y) dan dampaknya pada Kinerja Karyawan (z)- Pengujian Sub-Struktural 2

Tabel 4 Model Summary Sub-Struktural 2

Model Summary

\begin{tabular}{|l|l|r|r|r|}
\hline $\begin{array}{l}\text { Mode } \\
1\end{array}$ & $\mathrm{R}$ & $\mathrm{R}$ Square & $\begin{array}{c}\text { Adjusted } \mathrm{R} \\
\text { Square }\end{array}$ & $\begin{array}{c}\text { Std Error of } \\
\text { the Estimate }\end{array}$ \\
\hline 1 & $.729 \mathrm{~g}$ & .531 & .516 & .38635 \\
\hline
\end{tabular}

a. Fredictors: (Constant), $y_{1} \times 2, x_{1}$

Sumber : Hasil Pengolahan Data Peneliti (2011)

Dari Tabel 4, diketahui bahwa variabel Lingkungan kerja $\left(\mathrm{X}_{1}\right)$, Job Insecurity $\left(\mathrm{X}_{2}\right)$ dan Motivasi Kerja $(Y)$ terhadap Kinerja Karyawan $(Z)$ sebesar R Square $\left(R^{2}\right)$ adalah $0.531=53,1 \%$ dan besarnya pengaruh variabel lain yang mempengaruhi variabel Kinerja Karyawan $(Z)$ diluar penelitian ini adalah sebesar 46,9\%. sementara itu, besarnya koefisien jalur bagi variabel lain di luar penelitian yang mempengaruhi dapat dihitung melalui rumus sebagai berikut :

$$
\begin{aligned}
\rho_{z} \varepsilon_{2} & =\sqrt{1-R^{2}} \\
& =\sqrt{1-0.531} \\
& =0.684
\end{aligned}
$$


Tabel 5 Coefficient Sub-Sturktural 2

Coefficients $^{\mathrm{a}}$

\begin{tabular}{|c|c|c|c|c|c|c|}
\hline \multirow{2}{*}{\multicolumn{2}{|c|}{ Model }} & \multicolumn{2}{|c|}{ Unstandardized Coefficients } & \multirow{2}{*}{$\begin{array}{c}\begin{array}{c}\text { Standardized } \\
\text { Coefficients }\end{array} \\
\text { Beta } \\
\end{array}$} & \multirow[b]{2}{*}{$t$} & \multirow[b]{2}{*}{ Siq. } \\
\hline & & $\mathrm{B}$ & Std. Error & & & \\
\hline \multirow[t]{4}{*}{1} & (Constant) & 1.066 & .328 & & 3.246 & .002 \\
\hline & $\mathrm{x} 1$ & .148 & .075 & .153 & 1.992 & .049 \\
\hline & $x 2$ & -.020 & .065 & -.021 & -.302 & .033 \\
\hline & $\mathrm{y}$ & .572 & .069 & .646 & 8.332 & .000 \\
\hline
\end{tabular}

a. Dependent Variable: $z$

Sumber : Hasil Pengolahan Data Peneliti (2011)

$Z=\rho_{z x 1} X_{1}+\rho_{z x 2} X_{2}+\rho_{z y} Y+\rho_{z} \varepsilon_{2}$
$Z=0.153 X_{1}-0.021 X_{2}+0.646 Y+0.684 \varepsilon_{2}$

PENUTUP

Lingkungan kerja $\left(\mathrm{X}_{1}\right)$ dan Job Insecurity $\left(\mathrm{X}_{2}\right)$ berpengaruh terhadap Motivasi Kerja $(\mathrm{Y})$ sebesar $20,3 \%$ dan besarnya pengaruh variabel lain yang mempengaruhi variabel Motivasi Kerja (Y) diluar penelitian ini adalah sebesar 79,7\%. Hasil korelasi secara individu Lingkungan Kerja (x1) dengan Motivasi Kerja (Y) sebesar 18.83\% $\left(0.434^{2}\right.$ x 100\%), dan korelasi antara Job Insecurity (x2) dengan Motivasi Kerja (Y) sebesar 1.3\%.(-0.114² x 100\%).

Maka untuk meningkatkan motivasi kerja karyawan Outsourcing di Mall Lippo Cikarang perlu diperhatikan lingkungan kerja yang nyaman bagi para karyawannya, karena variable lingkungan kerja lebih berpengaruh terhadap variabel motivasi kerja. Akan tetapi variable Job Insecurity juga masih harus diperhatikan.

Variabel Lingkungan kerja, Job Insecurity dan Motivasi Kerja berpengaruh terhadap Kinerja Karyawan sebesar $53,1 \%$ dan besarnya pengaruh variabel lain yang mempengaruhi variabel Kinerja Karyawan diluar penelitian ini adalah sebesar 46,9\%. Korelasi secara individu Lingkungan Kerja (x1) dengan Kinerja Karyawan $(\mathrm{Z})$ : $18.83 \%\left(0.434^{2}\right.$ x 100\%), korelasi antara Job Insecurity (x2) dengan Kinerja Karyawan $(\mathrm{Z})$ : $0.85 \%\left(-0.092^{2} \times 100 \%\right)$, dan motivasi kerja(Y) dengan Kinerja Karyawan $(\mathrm{Z})$ : $51.1 \%\left(0.715^{2} \times 100 \%\right)$. Maka untuk meningkatkan Kinerja karyawan Outsourcing Mall Lippo Cikarang, perlu memperhatikan peningkatan motivasi kerja para karyawan nya karena variable Motivasi adalah variable yang paling berpengaruh kuat terhadap Kinerja karyawan. 


\section{DAFTAR PUSTAKA}

Basuki, \& Susilowati, I. (2005). Dampak kepemimpinan dan lingkungan kerja terhadap semangat kerja. Jurnal JRBI, Vol. 1, No. 1, Januari.

Bin Jiang, Frazier, G. V., \& Prater, E. L. (2006). Outsourcing effects on firms' operational performance: An empirical study. International Journal of Operations \& Production Management, Vol. 26 Iss: 12, pp.1280-1300.

George \& Jones. (2005). Understanding and managing organizational behaviour (4th ed.). Pearson Prentice Hall.

Mangkunegara, A. P. (2002). Manajemen sumber daya manusia perusahaan. Bandung: Remaja Rosdakarya.

Pasewark, W. R., \& Strawser, J. R. (2001). The Determinants and Outcomes Associated with Job Insecurity in a Professional Accounting Environment. Behavioral Research in Accounting, Vol. 8; p 91-113.

Riduwan. (2007). Metode dan teknik menyusun thesis. Bandung: Alfabeta.

Riduwan \& Kuncoro, E. A. (2008). Cara menggunakan dan memaknai analisis jalur. Bandung: Alfabeta.

Robert, M. L., \& John, J. H. (2006). Human resource management. Jakarta: Salemba Empat.

Rochaety, E., Tresnati, R., \& Latief, A. M. (2007). Metodologi penelitian bisnis: Dengan aplikasi SPSS. Jakarta: Mitra Wacana Media.3

Sedarmayanti. (2001) Sumber daya manusia dan produktivitas kerja. Bandung: Mandar Maju.

Sofyandi, H. (2008) Manajemen sumber daya manusia. Yogyakarta: Graha Ilmu.

Suwandi, \& Indriantoro, Nur. (2003). Pengujian model Turnover Pasewark dan Strawser: Studi empiris pada lingkungan akuntansi publik. Jurnal Riset Akuntansi Indonesia. Vol.2, Iss. 2, pg. 173-195. 